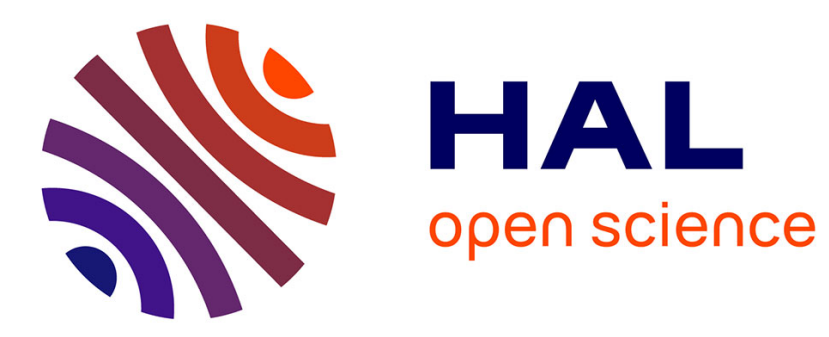

\title{
Energy Dispersive X-Ray Spectroscopy for the Determination of Trace and Main Elements
}

\author{
M. Haschke
}

\section{To cite this version:}

M. Haschke. Energy Dispersive X-Ray Spectroscopy for the Determination of Trace and Main Elements. Journal de Physique IV Proceedings, 1996, 06 (C4), pp.C4-619-C4-625. 10.1051/jp4:1996458 . jpa-00254341

\section{HAL Id: jpa-00254341 https://hal.science/jpa-00254341}

Submitted on 1 Jan 1996

HAL is a multi-disciplinary open access archive for the deposit and dissemination of scientific research documents, whether they are published or not. The documents may come from teaching and research institutions in France or abroad, or from public or private research centers.
L'archive ouverte pluridisciplinaire HAL, est destinée au dépôt et à la diffusion de documents scientifiques de niveau recherche, publiés ou non, émanant des établissements d'enseignement et de recherche français ou étrangers, des laboratoires publics ou privés. 


\title{
Energy Dispersive X-Ray Spectroscopy for the Determination of Trace and Main Elements
}

\author{
M. Haschke
}

SPECTRO Analytical Instruments, Kleve

\begin{abstract}
The results from various samples reported here show that energy dispersive x-ray spectroscopy is available as an efficient analytical method; one that has emerged from the qualitative and semiquantitative overview analysis phase.

Particularly the ability to improve sensitivity or reduce statistical error using optimized excitation has led to an important advancement in capturing the primary signal. The simultaneous measurement of a wide range of elements enables utilization of all of the information contained in a spectra for the evaluation; allowing for new approaches for the evaluation of spectra, particularly for the consideration of matrix influences.
\end{abstract}

\section{INTRODUCTION}

Many laboratories have already shown interest in energy dispersive x-ray spectroscopy. The reasons for this are:

- Different sample types (solid materials, liquids, powders, metals, minerals, etc.) can be analyzed with simple sample preparation.

- Analysis over a wide range of concentrations (from traces to main components) is possible without dilution.

- A wide range of elements can be analyzed simultaneously.

Energy dispersive $\mathrm{x}$-ray spectroscopy is, however, often viewed as a screening method. Using the results from various applications, this paper will show that this method is extremely flexible; that it can be viewed as a true alternative to wavelength dispersive $\mathrm{x}$-ray spectroscopy for many applications.

The results presented here were obtained with the SPECTRO X-LAB. This instrument is characterized by its use of special techniques for the excitation of fluorescence radiation. The sample is not directly excited. The tube radiation is modified by different targets in order to achieve optimal excitation for the given analytical application.

The different targets used and their advantages are summarized in table 1 . Up to 8 of these targets can be simultaneously utilized in one instrument. 
Table 1: Targets used in the SPECTRO X-LAB for optimization of the excitation conditions

\begin{tabular}{|c|c|c|c|}
\hline Target type & Excitation with & Result of the excitation & Application \\
\hline $\begin{array}{l}\text { BARKLA scatterer } \\
\text { example: } \\
\mathrm{B}_{4} \mathrm{C}, \mathrm{Al}_{2} \mathrm{O}_{3}\end{array}$ & polarized radiation & $\begin{array}{l}\text { reduced spectral } \\
\text { background due to } \\
\text { directionally } \\
\text { dependent scattering } \\
\text { of the polarized } \\
\text { radiation }\end{array}$ & $\begin{array}{l}\text { - trace analysis of hea- } \\
\text { vier elements in light } \\
\text { matrices (e.g., } \\
\text { geology, soil, oil, } \\
\text { plastic, biological } \\
\text { samples, etc.) }\end{array}$ \\
\hline $\begin{array}{l}\text { Secondary target } \\
\text { example: } \\
\text { Si, Co, } \mathrm{Zn}, \mathrm{Mo}, \mathrm{Pd} \text {, } \\
\text { Sm }\end{array}$ & $\begin{array}{l}\text { monoenergetic } \\
\text { characteristic radiation } \\
\text { of the target material }\end{array}$ & $\begin{array}{l}\text { Highly effective for } \\
\text { the excitation of } \\
\text { certain groups of } \\
\text { elements due to the } \\
\text { closeness of exciting } \\
\text { and excited radiation } \\
\text { energies }\end{array}$ & $\begin{array}{l}\text { - analysis of main } \\
\text { components } \\
\text { - trace analysis for } \\
\text { light elements } \\
\text { - analysis of small } \\
\text { sample amounts } \\
\text { - analysis of dust on } \\
\text { filters }\end{array}$ \\
\hline $\begin{array}{l}\text { Combination targets } \\
\text { example: } \\
\text { HOPG }\end{array}$ & $\begin{array}{l}\text { polarized } \\
\text { monoenergetic } \\
\text { radiation (Rh-L- } \\
\text { radiation) and } \\
\text { polarized } \\
\text { bremsstrahlung }\end{array}$ & $\begin{array}{l}\text { effective excitation of } \\
\text { lights elements due to } \\
\text { Rh-L-radiation, } \\
\text { measuring channels } \\
\text { are not overloaded by } \\
\text { excitation radiation, } \\
\text { because, due to } \\
\text { polarization, this is not } \\
\text { scattered }\end{array}$ & $\begin{array}{l}\text { - main component } \\
\text { analysis from } \mathrm{F} \text { to } \mathrm{Fe} \\
\text { with one excitation } \\
\text { - trace analysis of light } \\
\text { elements }\end{array}$ \\
\hline
\end{tabular}

\section{ANALYTICAL CAPABILITIES}

The analytical capabilities of a method or a measuring instrument are described by the following parameters:

- sensitivity (detection limits)

- precision (reproducibility)

- stability (longterm behavior)

- analytical exactness (correctness)

These parameters are displayed for energy dispersive x-ray spectroscopy for various analytical applications:

\subsection{Sensitivity}

The sensitivity of a method can be described by the achievable detection limits. The detection limit is calculated according to the IUPAC definition

$$
\mathrm{C}_{\mathrm{LOD}}=3\left(\sqrt{\mathrm{U}} / \mathrm{I}_{\mathrm{S}}\right) \mathrm{C}_{\mathrm{S}}
$$

The detection limits that can be achieved with various excitation parameters for several elements are summarized in table 2 . These values apply to silicate powders (for example geological samples, soils, slags). 
The high sensitivity for heavy elements is achieved by ecxitation with polarized radiation. This radiation gives improved peak-background-ratios for light matrices because of significantly reduced scattering in the polarization plane.

The results for the light elements were achieved with a special radiation entrance window.

Table 2: Detection limits for different excitation conditions in a silicate matrix (from $/ 1$ ) [in $\mu \mathrm{g} / \mathrm{g}$ ]

\begin{tabular}{|c|c|c|c|c|}
\hline $\begin{array}{c}\text { Atomic } \\
\text { number }\end{array}$ & Element & \multicolumn{3}{|c|}{ Detection limit } \\
\hline 11 & & BARKLA & Secondary & Secondary \\
12 & $\mathrm{MgO}$ & & $\mathrm{Cd}-2000$ & $\mathrm{Si}-150$ \\
13 & $\mathrm{Al}_{2} \mathrm{O}_{3}$ & & $\mathrm{Cd}-1000$ & $\mathrm{Si}-50$ \\
14 & $\mathrm{SiO}_{2}$ & & $\mathrm{Cd}-600$ & $\mathrm{HOPG}-30$ \\
15 & $\mathrm{P}_{2} \mathrm{O}_{5}$ & & $\mathrm{Cd}-120$ & $\mathrm{HOPG}-20$ \\
16 & $\mathrm{SO}_{4}$ & & $\mathrm{Cd}-30$ & HOPG -15 \\
17 & $\mathrm{Cl}$ & & $\mathrm{Cd}-10$ & HOPG - \\
20 & $\mathrm{CaO}$ & & $\mathrm{Co}-80$ & \\
22 & $\mathrm{TiO}$ & & $\mathrm{Co}-25$ & \\
29 & $\mathrm{Cu}$ & 0.9 & & \\
30 & $\mathrm{Zn}$ & 0.8 & & \\
33 & $\mathrm{As}$ & 0.6 & & \\
35 & $\mathrm{Br}$ & 0.6 & & \\
42 & $\mathrm{Mo}$ & 2.0 & & \\
48 & $\mathrm{Cd}$ & 0.3 & & \\
50 & $\mathrm{Sn}$ & 0.6 & & \\
56 & $\mathrm{Ba}$ & 2.5 & & \\
80 & $\mathrm{Hg}$ & 1.7 & & \\
82 & $\mathrm{~Pb}$ & 1.7 & & \\
\hline
\end{tabular}

An effective excitation is important for light elements because the fluorescent yield of this elements is small. The detection limits shown in table 2 for light elements are achieved with special targets ans with a special entrance window for the detector.

Secondary targets are more suited to the trace analysis of metals, because these allow selective excitation. Thus, it is possible to excite lighter trace elements without exciting the main components. Results from the analysis of precious metals are summarized in table 3. 
Table 3: Limits of detection for precious metal alloys (from $/ 2 /$ ) [in $\mu \mathrm{g} / \mathrm{g}$ ]

\begin{tabular}{|c|c|c|c|}
\hline Element & $\begin{array}{c}\text { Target } \\
\mathbf{A u} / \mathbf{A g}\end{array}$ & $\begin{array}{c}\text { Matrix } \\
\mathbf{A u}\end{array}$ & $\begin{array}{c}\text { Matrix } \\
\mathbf{A g}\end{array}$ \\
\hline $\mathrm{Cr}$ & $\mathrm{Zn}$ & 2 & - \\
$\mathrm{Mn}$ & $\mathrm{Zn}$ & 4 & - \\
$\mathrm{Co}$ & $\mathrm{Zn}$ & 2 & 1 \\
$\mathrm{Ni}$ & $\mathrm{Ge}$ & 5 & 3 \\
$\mathrm{Cu}$ & $\mathrm{Ge}$ & 9 & 3 \\
$\mathrm{Zn}$ & $\mathrm{Ge}$ & 5 & 2 \\
$\mathrm{As}$ & $\mathrm{Pd}$ & 25 & 20 \\
$\mathrm{Ag}$ & $\mathrm{Sm} /-$ & 6 & $\mathrm{n} . \mathrm{a}$. \\
$\mathrm{Sn}$ & $\mathrm{Sm} /-$ & 0.3 & 25 \\
$\mathrm{Sb}$ & $\mathrm{Sm} /-$ & 3 & 25 \\
$\mathrm{Te}$ & $\mathrm{Sm} /$ & 2 & 20 \\
$\mathrm{Pd}$ & $\mathrm{Sm} /$ & 4 & - \\
$\mathrm{Rh}$ & $\mathrm{Sm} /-$ & 4 & 50 \\
$\mathrm{Pt}$ & $-/ \mathrm{Pd}$ & - & 3 \\
$\mathrm{Au}$ & $-/ \mathrm{Pd}$ & n.a. & 13 \\
$\mathrm{Bi}$ & $-/ \mathrm{Pd}$ & 20 & 10 \\
$\mathrm{~Pb}$ & $-/ \mathrm{Pd}$ & 20 & 4 \\
\hline
\end{tabular}

Excitation with secondary targets is also very effective for the analysis of small sample amounts. Examples of detection limits for dust on filters are shown in table 4.

Table 4: Detection limits for filter dust (from /3/)

[in $\mathrm{ng} / \mathrm{cm}^{2}$ ]

\begin{tabular}{|c|c|c|}
\hline Element & \multicolumn{2}{|c|}{ Detection limit } \\
& membrane filter & quartz filter \\
\hline $\mathrm{Al}$ & - & 225 \\
$\mathbf{K}$ & - & 135 \\
$\mathrm{Ca}$ & 100 & 120 \\
$\mathrm{Cr}$ & 6 & 4.8 \\
$\mathrm{Mn}$ & 2 & 3.8 \\
$\mathrm{Fe}$ & 2 & 50 \\
$\mathrm{Ni}$ & 2.5 & 3.6 \\
$\mathrm{Cu}$ & 3 & 3.9 \\
$\mathrm{Zn}$ & 4 & 3.0 \\
$\mathrm{Ba}$ & - & 27 \\
$\mathrm{~Pb}$ & 8 & 4.2 \\
$\mathrm{Cd}$ & 4 & 6.0 \\
\hline
\end{tabular}

\subsection{Reproducibility}

The reproducibility of a method is determined by repeated measurements of the same sample. The results of measurements on a Basalt sample are presented here. The sample was prepared with a melt fusion and analyzed ten times.

The results of the individual measurements and the standard deviations for them are summarized for various elements in table 5 . 
Fusion tablets have a high homogeneity and a flat surface. The high reproducibility is a result of the low statistical error obtained by the high effective excitation.

Table 5: Reproducibility for a melt tablet (from /4/)

(Basalt sample, in \%, measuring time: $100 \mathrm{~s}$ with HOPG target)

\begin{tabular}{|c|c|c|c|c|c|c|c|c|c|c|c|c|c|}
\hline Meas. & 1 & 2 & 3 & 4 & 5 & 6 & 7 & 8 & 9 & 10 & Average & SD & RSD \\
\hline$\overline{\mathrm{MgO}}$ & 12,21 & 12,28 & 12,26 & 12,21 & 12,03 & 12,04 & $\overline{12,05}$ & 12,07 & 12,38 & 12,18 & 12,171 & 0,1198 & 0,0098 \\
\hline $\mathrm{Al} 2 \mathrm{O} 3$ & 12 & 12,17 & 12,01 & 12,1 & 12,07 & 12,09 & 12,09 & 12,2 & 12,11 & 12,06 & 12,09 & 0,0622 & 0,0051 \\
\hline $\mathrm{SiO} 2$ & 43,31 & 43,41 & 43,54 & 43,56 & 43,49 & 43,49 & 43,62 & 43,49 & 43,76 & 43,54 & 43,521 & 0.1197 & 0,0398 \\
\hline $\mathrm{P} 2 \mathrm{O} 5$ & 0,46 & 0,46 & 0,47 & 0,52 & 0,47 & 0,46 & 0,49 & 0,47 & 0,49 & 0,47 & 0,476 & 0,0189 & 0,0398 \\
\hline $\mathrm{K} 2 \mathrm{O}$ & 1,33 & 1,32 & 1,35 & 1,32 & 1,32 & 1,32 & 1,3 & 1,33 & 1,31 & 1,32 & 1,322 & 0,0132 & $.0,0099$ \\
\hline $\mathrm{CaO}$ & 11,2 & 11,26 & 11,2 & 11,2 & 11,26 & 11,3 & 11,24 & 11,2 & 11,31 & 11,15 & 11,222 & 0,0655 & 0,0058 \\
\hline $\mathrm{TiO} 2$ & 2,41 & 2,41 & 2,42 & 2,42 & 2,42 & 2,43 & 2,4 & 2,42 & 2,42 & 2,41 & 2,416 & 0,0084 & 00035 \\
\hline $\mathrm{Cr} 2 \mathrm{O} 3$ & 0,06 & 0,06 & 0,06 & 0,06 & 0,06 & 0,06 & 0,06 & 0,06 & 0,06 & 0,06 & 0,06 & 0 & 0 \\
\hline $\mathrm{MnO}$ & 0,19 & 0,19 & 0,19 & 0,19 & 0,19 & 0,19 & 0,19 & 0,19 & 0,19 & 0,19 & 0,19 & 0 & $\mathbf{0}$ \\
\hline $\mathrm{Fe} 2 \mathrm{O} 3$ & 12,29 & 12,34 & 12,31 & 12,35 & 12,34 & 12,4 & 12,35 & 12,36 & 12,36 & 12,34 & 12,344 & 0.0295 & 0,0024 \\
\hline
\end{tabular}

When analyzing powder samples, low reproducibilities of light elements are obtained as a result of grain size and surface influences. The values for 7 measurements on a stone sample are given in table 6.

Table 6: Standard deviations for powder samples

\begin{tabular}{|c|c|c|c|c|c|c|c|c|c|c|}
\hline Element & $\mathbf{1}$ & $\mathbf{2}$ & $\mathbf{3}$ & $\mathbf{4}$ & $\mathbf{5}$ & $\mathbf{6}$ & $\mathbf{7}$ & Average & SD & RSD \\
\hline $\mathrm{Al} 2 \mathrm{O} 3[\%]$ & 14,61 & 14,28 & 14,39 & 14,53 & 14,24 & 14,43 & 14,38 & 14,408 & 0.1303 & 0.0090 \\
$\mathrm{SiO} 2[\%]$ & 67,86 & 67,40 & 66,74 & $\mathbf{6 8 , 3 3}$ & 66,31 & 67,21 & $\mathbf{6 8 . 0 4}$ & 67.27 & $\mathbf{0 . 8 1 9 3}$ & $\mathbf{0 , 0 1 2 1}$ \\
$\mathrm{MnO}[\mu \mathrm{g} / \mathrm{g}]$ & 1783 & 1736 & 1767 & 1775 & 1753 & 1743 & 1749 & 1758 & 17 & 0.0098 \\
$\mathrm{Fe} 2 \mathrm{O} 3[\%]$ & 6,191 & 6,213 & 6,260 & 6,163 & $\mathbf{6 , 1 5 5}$ & 6,189 & $\mathbf{6 , 1 6 2}$ & 6,190 & 0.0369 & 0.0059 \\
$\mathrm{Rb}[\mu \mathrm{g} / \mathrm{g}]$ & 2013 & 2000 & 2023 & 2011 & 2006 & 2010 & 2027 & 2012 & 0,9 & $\mathbf{0 , 0 0 4 6}$ \\
$\mathrm{Sn}[\mu \mathrm{g} / \mathrm{g}]$ & 1894 & 1851 & 1885 & 1873 & 1877 & 1882 & 1872 & 1876 & 1,3 & 0,0071 \\
$\mathrm{~Pb}[\mu \mathrm{g} / \mathrm{g}]$ & 20,1 & 19,6 & 28,0 & 20,6 & 18,5 & 19,5 & 19,2 & 20,78 & 3,2 & 0,156 \\
\hline
\end{tabular}

The influence of sample preparation on the reproducibility can be neglected for these examinations,. When these influences are taken into consideration, the standard deviation is markedly increased; factors from 2 - 5 may occur depending on sample homogeneity, care in sample preparation and sample quality.

\subsection{Longterm Stability}

The longterm stability of an instrument is a measure of the reliability of the analysis over a longer period of time or of the necessity for regular standardizations.

Energy dispersive x-ray spectroscopy, with its simultaneous measurement of a wide range of elements, offers method specific standardization based on a current measurement. In this way:

- the energy-channel relationship for each spectra can be standardized, as several x-ray lines are always clearly identifiable or

- influences from instabilities in the excitation or from detection effects can be compensated for by using the relationship of line intensities on scattering intensities. 
The longterm stability is displayed in table 7 using measurements on the same standard sample over a period of 8 months.

Table 7: Longterm stability of the SPECTRO X-LAB using daily measurements of the GSS 1 standard sample (from $/ 5 /$ )

\begin{tabular}{|c|c|c|c|c|c|c|}
\hline \multirow[t]{2}{*}{ Element } & \multicolumn{2}{|c|}{$\begin{array}{l}\text { Reference sample } \\
\text { GSS1 }\end{array}$} & \multicolumn{4}{|c|}{ SPECTRO X-LAB } \\
\hline & $\begin{array}{l}\mathrm{C}_{\text {cert }} \\
{[\mu \mathrm{g} / \mathrm{g}]}\end{array}$ & $\begin{array}{l}\text { SD } \\
{[\mu \mathrm{g} / \mathrm{g}]}\end{array}$ & $\begin{array}{l}C_{a v} \\
{[\mu g / g]}\end{array}$ & $\begin{array}{l}\mathrm{SD}_{\text {abs }} \\
{[\mu \mathrm{g} / \mathrm{g}]}\end{array}$ & $\begin{array}{l}\text { RSD } \\
{[\%]}\end{array}$ & $\begin{array}{l}\operatorname{RSD}_{\{\text {month }} \\
{[\%]}\end{array}$ \\
\hline$\overline{\mathrm{Ti}}$ & 8056 & 417 & 7921 & 203.0 & 2.56 & 1.61 \\
\hline $\mathrm{Zn}$ & 680 & 53 & 666.24 & 7.95 & 1.19 & 1.18 \\
\hline $\mathrm{Sr}$ & 155 & 10 & 155.3 & 1.58 & 1.02 & 1.02 \\
\hline $\mathrm{Cd}$ & 4.3 & 0.6 & 5.01 & 0.5 & 10.1 & 5.38 \\
\hline $\mathrm{Ba}$ & 590 & 50 & 551.2 & 10.5 & 1.91 & 1.06 \\
\hline $\mathrm{Pb}$ & 98 & 8 & 97.2 & 1.78 & 1.8 & 2.04 \\
\hline
\end{tabular}

\subsection{Analytical Exactness}

The assessment of the analytical exactness is often the deciding criteria for the evaluation of the capabilities of an analytical instrument. Normally, however, this question can only be decided as a comparison with other methods. This can take place in different ways:

- analysis of samples with known contents (reference materials)

- participation in round robin tests

To validate energy dispersive $x$-ray spectroscopy, examinations with the SPECTRO X-TEST were conducted with all of the above named methods.

\section{Comparison with Reference Materials}

This method is the simplest and is the standard method for the calibration of a spectrometer. These types of comparisons are summarized for main components and trace elements in several geological samples in tables 8 and 9. 
Table 8: Comparison of analytical results for main components (from /6/) (Samples prepared as melt tablets) [in \%]

\begin{tabular}{|l|r|r|r|r|r|r|r|r|}
\hline Sample & \multicolumn{2}{|c|}{ PFA 1 } & \multicolumn{2}{|c|}{ KH } & \multicolumn{2}{c|}{ BHVO-1 } & \multicolumn{2}{c|}{ RGM-1 } \\
Element & Expect & \multicolumn{1}{|c|}{ X-LAB } & Expect & \multicolumn{1}{c|}{ X-LAB } & Expect & X-LAB & Expect & \multicolumn{1}{c|}{ X-LAB } \\
\hline $\mathrm{Na}_{2} \mathrm{O}$ & 1,31 & $1,28 \pm 0,18$ & 0,43 & $<0,1$ & 2,64 & $2,13 \pm 0,19$ & 4,05 & $4,07 \pm 0,18$ \\
$\mathrm{MgO}$ & 1,54 & $1,63 \pm 0,08$ & 0,77 & $0,73 \pm 0,12$ & 7,30 & $7,35 \pm 0,12$ & 0,33 & $0,33 \pm 0,06$ \\
$\mathrm{Al}_{2} \mathrm{O}_{3}$ & 26,7 & $26,55 \pm 0,13$ & 2,28 & $2,40 \pm 0,05$ & 13,7 & $13,69 \pm 0,10$ & 13,7 & $13,70 \pm 0,09$ \\
$\mathrm{SiO}_{2}$ & 51,5 & $51,61 \pm 0,20$ & 8,70 & $8,60 \pm 0,07$ & 50,1 & $50,04 \pm 0,19$ & 72,9 & $73,3 \pm 0,18$ \\
$\mathrm{P}_{2} \mathrm{O}_{5}$ & 0,27 & $0,29 \pm 0,01$ & 0,11 & $0,12 \pm 0,02$ & 0,27 & $0,30 \pm 0,01$ & 0,04 & $0,07 \pm 0,01$ \\
$\mathrm{SO}_{3}$ & 0,44 & $0,59 \pm 0,01$ & 0,28 & $0,33 \pm 0,01$ & 0,06 & $0,06 \pm 0,01$ & 0,06 & $<0,02$ \\
$\mathrm{~K}_{2} \mathrm{O}$ & 3,76 & $3,89 \pm 0,02$ & 0,44 & $0,41 \pm 0,00$ & 0,53 & $0,54 \pm 0,01$ & 4,30 & $4,41 \pm 0,02$ \\
$\mathrm{CaO}$ & 1,09 & $1,14 \pm 0,01$ & 47,2 & $47,99 \pm 0,07$ & 11,5 & $11,55 \pm 0,03$ & 1,15 & $1,20 \pm 0,01$ \\
$\mathrm{TiO}_{2}$ & 0,97 & $0,96 \pm 0,01$ & 0,11 & $0,14 \pm 0,01$ & 2,76 & $2,75 \pm 0,01$ & 0,26 & $0,27 \pm 0,01$ \\
$\mathrm{MnO}$ & 0,06 & $0,07 \pm 0,02$ & 0,07 & $0,08 \pm 0,00$ & 0,17 & $0,17 \pm 0,01$ & 0,03 & $0,04 \pm 0,00$ \\
$\mathrm{Fe}_{2} \mathrm{O}_{3}$ & 9,37 & $9,27 \pm 0,02$ & 0,77 & $0,84 \pm 0,01$ & 12,4 & $12,21 \pm 0,02$ & 1,87 & $1,90 \pm 0,01$ \\
\hline
\end{tabular}

Table 9: Comparison of analytical results for trace elements (from /6/) (Samples prepared as powder tablets) [in $\mu \mathrm{g} / \mathrm{g}$ ]

\begin{tabular}{|l|r|r|r|r|r|r|r|r|}
\hline Sample & \multicolumn{2}{|c|}{ GXR 4 } & \multicolumn{2}{c|}{ GXR 6 } & \multicolumn{2}{c|}{ BCR 141 } & \multicolumn{2}{c|}{ SOIL 7 } \\
Element & Expect & \multicolumn{1}{|c|}{ X-LAB } & Expect & \multicolumn{1}{c|}{ X-LAB } & Expect & X-LAB & Expect & \multicolumn{1}{c|}{ X-LAB } \\
\hline $\mathrm{Cr}$ & 64.0 & $76.1 \pm 1.5$ & 96.0 & $93.8 \pm 1.6$ & $(75)$ & $69.9 \pm 1.5$ & 60.0 & $68.2 \pm 2.1$ \\
$\mathrm{Ni}$ & 42.0 & $35.2 \pm 1.5$ & 27.0 & $28.3 \pm 1.0$ & $(28)$ & $33.8 \pm 1.0$ & - & $28.2 \pm 1.0$ \\
$\mathrm{Cu}$ & 6520.0 & $6556 \pm 14$ & 66.0 & $64.2 \pm 1.3$ & 32.6 & $32.9 \pm 0.9$ & 11.0 & $12.9 \pm 0.6$ \\
$\mathrm{Zn}$ & 73.0 & $81.4 \pm 1.5$ & 118.0 & $127 \pm 1.5$ & 81.3 & $77.2 \pm 1.1$ & 104.0 & $100 \pm 1.3$ \\
$\mathrm{As}$ & 98.0 & $103 \pm 1.1$ & 330.0 & $316 \pm 2$ & $(5.4)$ & $6.3 \pm 0.5$ & 13.4 & $11.8 \pm 0.7$ \\
$\mathrm{Br}$ & - & $<0.6$ & $(1.4)$ & $2.0 \pm 0.4$ & $(5.0)$ & $4.0 \pm 0.2$ & - & $20.0 \pm 0.3$ \\
$\mathrm{Cd}$ & $(0.9)$ & $0.6 \pm 0.2$ & $(1.0)$ & $<0.3$ & 0.4 & $0.6 \pm 0.2$ & - & $1.6 \pm 0.2$ \\
$\mathrm{Sn}$ & 5.6 & $6.4 \pm 0.3$ & $(1.7)$ & $1.5 \pm 0.2$ & $(4.0)$ & $4.8 \pm 0.3$ & - & $2.8 \pm 0.2$ \\
$\mathrm{Ba}$ & 1640.0 & $1832 \pm 3$ & 1300.0 & $1540 \pm 2$ & $(980)$ & $280 \pm 2$ & - & $201.5 \pm 2$ \\
$\mathrm{~Pb}$ & 52.0 & $54.6 \pm 1.3$ & 101.0 & $98.7 \pm 1.5$ & 29.4 & $29.4 \pm 1.0$ & 60.0 & $68.4 \pm 1.3$ \\
\hline
\end{tabular}

\section{Acknowledgments}

Measurements from the following were used for this release:

/1/ Landesumweltamt NRW, Recklinghausen

12/ Staatliche Bank von Kasachstan, Almaty

13/ Institut für anorganische und analytische Chemie der Universität Hamburg

14/ Rockwool Lapinus B.V., Roermond

/5/ Gesellschaft für Wirtschafts- und Umweltgeologie, Berlin

/6/ Institute of Geology, University of Sheffield 